\title{
Sprawozdanie z XXII. Międzynarodowej Konferencji Naukowej Socialia 2018 - Ohrožení jedince v současné společnosti. Hradec Králové, 18-19 października 2018 r.
}

W dniach 18-19 października 2018 r. w położonym na terenie Republiki Czeskiej Hradec Králové odbyła się XXII Międzynarodowa Konferencja Naukowa Socialia 2018 zatytyułowana „Ohrožení jedince v současné společnosti“ (Zagrożenia dla jednostki we współczesnym społeczeństwie). Jej organizatorem była Katedra Patologii Społecznych i Socjologii Wydziału Edukacji Uniwersytetu Hradec Králové, a rolę współorganizatorów pełniły: Katedra Pedagogiki Społecznej tegoż wydziału, Katedra Pedagogiki Wydziału Pedagogiki Uniwersytetu Mateja Beli w Bańskiej Bystrzycy na Słowacji oraz Katedra Pedagogiki Wyższej Szkoły Biznesu w Dąbrowie Górniczej. Patronat nad wydarzeniem objął senator JUDr. Miroslav Antl, przewodniczący Komisji Konstytucyjnej i Prawnej Senatu Parlamentu Republiki Czeskiej.

Konferencja była XXII edycją międzynarodowych spotkań pedagogów, praktyków oraz przedstawicieli innych nauk społecznych, pochodzących z jednostek badawczych krajów Europy Środkowo-Wschodniej, którzy w międzynarodowym gronie spotykają się na corocznych ${ }^{1}$ konferencjach pod wspólną nazwą „Socialia”. Początkowe seminaria o tej nazwie odbywały na Wydziale Edukacji Uniwersytetu Hradec Králové, następnie

${ }^{1}$ W tym roku wyjątkowo odbyły się dwie konferencje Socialia. Obok tej omawianej miała miejsce kolejna edycja konferencji. W dniach 15-16 listopada odbyła się XXIII Międzynarodowa Konferencja Naukowa Socialia 2018 zatytułowana: Społeczno-pedagogiczne problemy współczesnej Europy. Kompetencje społeczne $w$ procesie redukcji deficytów $i$ rozwiązywania problemów jednostki oraz wspólnoty. Jej organizatorem była Wyższa Szkoła Biznesu w Dąbrowie Górniczej, a współorganizatorami wydziały pedagogiki z czeskiego Uniwersytetu w Hradec Králové oraz słowackiego Uniwersytetu Mateja Beli w Bańskiej Bystricy. Organizatorzy wystąpili o objęcie wydarzenia patronatem honorowym m.in. do: Ministerstwa Nauki i Szkolnictwa Wyższego, Ministerstwa Edukacji Narodowej, Prezydenta Dąbrowy Górniczej, Komitetu Nauk Pedagogicznych PAN oraz Polskiego Towarzystwo Pedagogicznego. 
także na Wydziale Pedagogiki Uniwersytetu Mateja Beli w Bańskiej Bystricy. W 2013 r. do organizacji tychże spotkań przystąpiła Katedra Pedagogiki Wyższej Szkoły Biznesu w Dąbrowie Górniczej. Wtedy to odbyła się pierwsza edycja polskich Socialii zatytułowana „Człowiek w obliczu wielkiej zmiany - wyzwania dla subdyscyplin współczesnej pedagogiki”. W wyniku współpracy wspomnianych uczelni kolejne edycje konferencji odbywają się naprzemiennie w trzech krajach.

Otwarcie tegorocznej (2018 r.) konferencji miało miejsce 18 października w auli budynku Wydziału Edukacji Uniwersytetu Hradec Králové. Licznie zgromadzonych uczestników konferencji, a także studentów i pracowników Wydziału powitali m.in.: doc. PhDr. Václav Bělík, Ph.D. oraz prof. PhDr. Blahoslav Kraus, CSc. - obaj z Katedry Patologii Społecznych i Socjologii, a nastepnie JUDr. Miroslav Antl - senator czeskiego parlamentu, przewodniczący konstytucyjnej komisji prawnej senatu parlamentu Republiki Czeskiej, członek Departamentu Patologii Społecznej i Socjologii UDF

Pierwszą sesję stanowiła dyskusja panelowa ,Zagrożenie jednostki (dziecka) we współczesnym społeczeństwie - wybrane problemy". Do udziału w wymianie poglądów zostali poproszeni: JUDr. Miroslav Antl, prof. PhDr. Blahoslav Kraus, oraz PhDr. Erich Stündl - filantrop i wizjoner, Koordynator ds. Prewencji Kryminalnej z miasta Svitavy. Tę dwugodzinną część konferencji poprowadził doc. PhDr. Václav Bělík.

Po przerwie obiadowej w hallu budynku miała prezentacja zatytułowana „Aktualne trendy w zapobieganiu i rozwiązywaniu indywidualnych zagrożeń”. Była to demonstracja działań podejmowanych przez organizacje współpracujące z Wydziałem, które na co dzień zajmują się profilaktyką, prewencją oraz zwalczaniem zagrożeń społecznych. Jedną z organizacji prezentujących swoją działalność było Centrum Prewencji Pierwotnej Semiramis, organizacja non-profit, działającą od 2000 r., mająca swoje siedziby w Nymburku i Hradec Králové. Terenem działalności Semiramis są Środkowe Czechy, Hradec Králové i Pardubice. Szeroka działalność organizacji polega m.in. na pracy na rzecz dzieci i wychowawców szkół podstawowych przez wdrażanie programów długotrwałej podstawowej profilaktyki zachowań ryzykownych zarówno o charakterze promującym zdrowy styl życia, jak i te dotyczące uzależnień. Centrum prowadzi także rozbudowaną działalność poradniczą, i szkoleniową dla nauczycieli i rodziców.

W godzinach popołudniowych odbywały się obrady w czterech sekcjach równoległych. W sekcji pierwszej swoje referaty prezentowali studenci studiów pedagogicznych uczących się w Czechach i na Słowacji. Tematyka wystąpień dotyczyła m.in. cyberprzestępczości, wartości i norm młodzieży w czasie wolnym, symboli społecznych w kontekście zachowania współczesnej młodzieży, zagrożenia uczniów środowiskiem wirtualnym, wspierania umiejętności czytania dzieci z domów dziecka, trendów rozwojowych przestępczości nieletnich oraz sposobów zapobiegania zachowaniom ryzyka na świecie. Druga sekcja prezentowała wyniki badań dotyczące problemów współczesnej rodziny. Wśród poruszanych zagadnień pojawiły się takie tematy, jak: marginalizacja i wykluczenie dorosłych osób z niepełnosprawnością intelektualną, samobójstwa i próby samobójcze w Polsce wśród dzieci i młodzieży, środowisko rodzinne dorastających dzieci z poczu- 
ciem osamotnienia; obraz funkcjonowania rodziny z problemem alkoholowym w percepcji jej członków, zachowania ryzykowne rodziców wobec dziecka prenatalnego, idea i codzienność współczesnej profilaktyki społecznej. Obrady trzeciej sekcji koncentrowały się wokół tematu zagrożeń dla dzieci we współczesnym społeczeństwie, a prelegenci w swoich wystąpieniach poruszali takie kwestie, jak: zagrożenia i zachowania ryzykowne dzieci i młodzieży jako temat zainteresowania pedagogiki społecznej - aspekty historyczne i współczesne; przygotowanie dzieci do opuszczenia domu dziecka jako sposób zapobiegania nieudanej integracji ze społeczeństwem, ryzykowne zachowania seksualne w świecie wirtualnym - możliwości zapobiegania, zagrożenia dla dzieci i młodzieży we współczesnym społeczeństwie i możliwości im zapobiegania w szkole, wykorzystanie efektu międzypokoleniowego w zapobieganiu zachowaniom ryzyka, kradzieże w szkole jako problem interpersonalny. Czwarta sekcja nosiła tytuł „Interdyscyplinarne konteksty zagrożeń jednostki”. Wygłoszone referaty dotyczyły m.in. takich kwestii, jak: edukacja seksualna jako profilaktyka, zagrożenia jednostki we współczesnym społeczeństwie a jednostka zagrażająca współczesnemu społeczeństwu, zapobieganie zachowaniom ryzyka w świecie wirtualnym w krajach V4, seniorzy i ryzyko ich obciążeń wysiłkowych, wpływ rówieśników na przestępczość nieletnich, programy lecznicze jako narzędzie do zmniejszenia ryzyka nawrotu choroby, kwestia agresji i użycia środków przymusu w obecnym czeskim systemie więziennictwa. Pierwszy dzień obrad zakończyła uroczysta kolacja o charakterze integracyjnym, której towarzyszyła oprawa muzyczna.

W drugim dniu konferencji obrady były podzielone na dwie sekcje. W zakres poruszanej tematyki wchodziły zagadnienia związane z grupami ryzyka oraz koncepcji rozwiązywania problemów społecznych. W trakcie jej trwania wygłoszone zostały referaty poświęcone takim kwestiom, jak: rola szkoły w życiu uczniów z doświadczeniem migracyjnym, edukacja polskich dzieci w Austrii - oczekiwania i napotkane trudności, wychowanie interkulturowe małego dziecka, zagrożenia jednostki we współczesnej rzeczywistości, subkultura punk w Polsce - od buntu do stylizacji, niewłaściwe postawy społeczne jako źródło zagrożeń dla osób w starszym wieku, działalność socjalna i edukacyjna joannitów w Poznaniu (średniowiecze - czasy współczesne). Z kolei referaty drugiej sekcji zatytułowanej „Możliwe podejścia do zapobiegania i rozwiązywania problemów społecznych" dotyczyły m.in. takich obszarów, jak: rodziny wieloproblemowe i możliwości interwencji, dziecko jako projekt rodzicielski w obecnej rodzinie, problemy profesjonalizacji profilaktyki zachowań ryzykownych w środowisku szkolnym, czynniki zagrażające współczesnemu człowiekowi. Po zakończonych obradach organizatorzy podziękowali uczestnikom za przybycie oraz zaprosili na kolejną edycję konferencji. 